\title{
Androgen Metabolism Gene Polymorphisms, Associations with Prostate Cancer Risk and Pathological Characteristics: A Comparative Analysis between South African and Senegalese Men
}

\author{
Pedro Fernandez, ${ }^{1}$ Charnita M. Zeigler-Johnson, ${ }^{2}$ Elaine Spangler, ${ }^{2}$ \\ André van der Merwe, ${ }^{1,3}$ Mohamed Jalloh, ${ }^{4}$ Serigne M. Gueye, ${ }^{4}$ and Timothy R. Rebbeck ${ }^{2}$ \\ ${ }^{1}$ Department of Urology, Stellenbosch University, P.O. Box 19063, Cape Town 7505, South Africa \\ ${ }^{2}$ Department of Biostatistics and Epidemiology and Abramson Cancer Center, Perelman School of Medicine, \\ University of Pennsylvania, Philadelphia, PA 19104, USA \\ ${ }^{3}$ Department of Urology, Tygerberg Hospital, Cape Town 7505, South Africa \\ ${ }^{4}$ University Cheikh Anta Diop and Hôpital Général de Grand Yoff, Dakar, Senegal
}

Correspondence should be addressed to Pedro Fernandez, pf3@sun.ac.za

Received 25 May 2012; Revised 3 August 2012; Accepted 20 August 2012

Academic Editor: Camille Ragin

Copyright (c) 2012 Pedro Fernandez et al. This is an open access article distributed under the Creative Commons Attribution License, which permits unrestricted use, distribution, and reproduction in any medium, provided the original work is properly cited.

Prostate cancer is the most common cancer in men in developed countries and the leading cause of mortality in males in less developed countries. African ethnicity is one of the major risk factors for developing prostate cancer. Pathways involved in androgen metabolism have been implicated in the etiology of the disease. Analyses of clinical data and CYP3A4, CYP3A5, and SRD5A2 genotypes were performed in South African White (120 cases; 134 controls), Mixed Ancestry (207 cases; 167 controls), and Black ( 25 cases; 20 controls) men, as well as in Senegalese men ( 86 cases; 300 controls). Senegalese men were diagnosed earlier with prostate cancer and had higher median PSA levels compared to South African men. Metastasis occurred more frequently in Senegalese men. Gene polymorphism frequencies differed significantly between South African and Senegalese men. The CYP3A4 rs2740574 polymorphism was associated with prostate cancer risk and tumor aggressiveness in South African men, after correction for population stratification, and the SRD5A2 rs523349 CG genotype was inversely associated with high-stage disease in Senegalese men. These data suggest that variants previously associated with prostate cancer in other populations may also affect prostate cancer risk in African men.

\section{Introduction}

Prostate cancer is the most common cancer in men from industrialized developed countries, and worldwide, the second most common of all malignancies in men [1-3]. The highest rates of prostate cancer are observed in AfricanAmerican men in the United States of America (USA) and Caribbean men of African descent [1,4], while the highest disease-associated mortality rates are observed in less developed countries that include regions of the Caribbean, Sub-Saharan Africa, and South America [3]. These data lend support to the suggestion that the African ethnicity is one of the major risk factors for prostate cancer $[5,6]$.
Although comprehensive cancer registries are limited in Africa, available data indicate that prostate cancer accounts for approximately $10.6 \%$ and $4.8 \%$ of all cancers in males in Sub-Saharan Africa and North Africa, respectively [7].

In Southern Africa (South Africa) and Western Africa (Nigeria and Cameroon), prostate cancer is the most commonly diagnosed cancer in males; however, the incidence of prostate cancer in Southern Africa is double that observed in Western Africa [8]. The reported age-standardized rate of histologically diagnosed prostate cancer in South Africa is 74.4 per 100000 males in the White population (European ancestry), 48 per 100000 males in the South African Mixed Ancestry population (a unique population group 
of Khoisan, European, African, and Asian ancestry that emerged in the 1700-1800 s; sometimes referred to South African Coloured) [9], and 17.2 per 100000 males in the Black population (African ancestry) [10]. However, the low reported incidence rate in South African Black men may be due to underreporting and underdiagnosis as a result of poor access to medical facilities [11]. Additionally, South African Black men present with a higher-grade and -stage disease, have higher serum prostate specific antigen (PSA) levels and receive potentially curative treatment less often than White or Mixed Ancestry men [12].

The clinical characteristics of prostate cancer among Senegalese men were found to be different from AfricanAmerican and Caucasian-American men [13]. Additionally, Senegalese men were most often diagnosed later with prostate cancer-related symptoms and at a worse tumor stage [13]. Senegalese and Asian-Indian men were also shown to be more likely to present with advanced disease compared to African-American and Caucasian-American men [14]. A more recent investigation determined that prostate cancer had a prevalence of $3.8 \%$ in Senegalese men [15]. The same study also reported that prostatic intraepithelial neoplasia (PIN), which is considered to be a precancerous lesion [16], was detected in $29.1 \%$ of men in their study population.

Because of the known hormone dependence of prostate cancer, genetic alterations in androgen metabolism pathways are likely to play a role in conferring genetic susceptibility to the disease. The androgen metabolism genes CYP3A4 and CYP3A5, which encode proteins belonging to the cytochrome P450 (CYP) family of enzymes that are involved in the metabolism of xenobiotics, steroids, vitamins, and sex hormones, have been implicated in prostate cancer risk [17-21]. Other studies have demonstrated associations between polymorphisms in the steroid 5-alpha reductase gene (SRD5A2), which encodes an enzyme that converts testosterone to dihydrotestosterone (DHT), and the risk of developing prostate cancer or disease severity [22-26]. We previously described genetic associations between polymorphisms in androgen metabolism genes, and risk of developing prostate cancer in South African men [27] and reported differences in genotype and allele frequencies between Senegalese, African-American, Caucasian-American and Ghanaian men for CYP3A4 and SRD5A2 [28]. In the present study, we extended our previous investigations by including additional participants and compared clinical information and genotype data for polymorphisms in CYP3A4, CYP $3 A 5$, and SRD5A2 between South African and Senegalese men. We describe differences in age at diagnosis, PSA levels, and metastasis in South African and Senegalese men. In addition, we show that genotype and allele frequencies in androgen metabolism genes differ between South African and Senegalese men and report on genetic associations with prostate cancer risk and disease aggressiveness.

\section{Materials and Methods}

2.1. South African Study Population. Categorization of all the study participants into different ethnic groups was based on self-identity. The study population comprising 120 White cases, 207 Mixed Ancestry cases, and 25 Black cases with histologically confirmed prostate cancer and no prior cancer at any other site were recruited from the Department of Urology, Tygerberg Hospital (Cape Town, South Africa). Clinical characteristics including PSA, Gleason grade, tumour node metastasis (TNM) stage, age at diagnosis, and other cancer diagnoses were obtained from medical records. All cases underwent radical prostatectomy, transurethral resection of the prostate, or prostatic biopsy and had histologically confirmed prostate cancer. Controls were selected among subjects admitted to Tygerberg Hospital for routine PSA examinations or benign prostatic hyperplasia $(\mathrm{BPH})$ and comprised of 134 White men, 167 Mixed Ancestry men, and 20 Black men that were matched for ethnicity (self-reported) and were from the same geographical region. Inclusion criteria for controls were PSA levels of $\leq 4.0 \mathrm{ng} / \mathrm{mL}$ and a normal digital rectal examination (DRE). Four Mixed Ancestry men with a PSA $\geq 4.0 \mathrm{ng} / \mathrm{mL}$ and/or an abnormal DRE, but who were negative for prostate cancer upon histological examination, were included as controls. Individuals with a prior diagnosis of cancer at any other site were excluded from the study.

2.2. Senegalese Study Population. The study population comprising 86 cases with histologically confirmed prostate cancer, advanced disease status with prostatic presentation at DRE or the existence of metastasis highly suggestive of prostate cancer, and with no prior cancer at any other site, were recruited from the Hôpital Général de Grand Yoff (Dakar, Senegal) and had undergone radical prostatectomy, transurethral resection of the prostate, or prostatic biopsy. A standardized questionnaire and review of medical records were used to obtain clinical information relevant to the study. Hospital and community-based controls were comprised of 300 men from the same geographical region. Inclusion criteria for Senegalese controls were PSA levels $\leq 4.0 \mathrm{ng} / \mathrm{mL}$ and normal DRE, or negative histology for prostate cancer. Individuals with a prior diagnosis of cancer at any other site were excluded from the study.

All study subjects consented to participate in the study and allowed their biological samples to be genetically analyzed, according to the Declaration of Helsinki (1964). The study was approved by the Stellenbosch University Health Research Ethics Committee, and the Institutional Review Boards of the Hôpital Général de Grand Yoff and the University of Pennsylvania.

2.3. Genotyping Analysis. Blood and buccal swabs were collected from South African and Senegalese men, respectively. Genomic deoxyribonucleic acid (DNA) was extracted from all samples using the QIAamp DNA Blood kit (Qiagen, Germany) and QIAamp 96 DNA Buccal Swab BioRobot kit (Qiagen, Valencia, CA). For the South African samples, the CYP3A4 rs2740574 and CYP3A5 rs776746 polymorphisms were analyzed as previously described [27]. For the Senegalese samples, the CYP3A4 rs2740574 and CYP3A5 rs776746 were analyzed using the methods described previously 
TABLe 1: Description of clinical characteristics among South African and Senegalese prostate cancer cases and controls.

\begin{tabular}{|c|c|c|c|c|c|c|c|c|c|}
\hline \multirow{3}{*}{ Variables of interest } & \multicolumn{4}{|c|}{ South Africa } & \multicolumn{5}{|c|}{ Senegal } \\
\hline & \multicolumn{2}{|c|}{ White } & \multicolumn{2}{|c|}{ Mixed } & \multicolumn{2}{|c|}{ Black } & \multicolumn{2}{|c|}{ Senegalese } & \multirow[t]{2}{*}{$P$} \\
\hline & $\begin{array}{l}\text { Controls } \\
(n=134)\end{array}$ & $\begin{array}{c}\text { Cases } \\
(n=120) \\
\end{array}$ & $\begin{array}{l}\text { Controls } \\
(n=167) \\
\end{array}$ & $\begin{array}{c}\text { Cases } \\
(n=207) \\
\end{array}$ & $\begin{array}{l}\text { Controls } \\
(n=20) \\
\end{array}$ & $\begin{array}{c}\text { Cases } \\
(n=25) \\
\end{array}$ & $\begin{array}{l}\text { Controls } \\
(n=300)\end{array}$ & $\begin{array}{c}\text { Cases } \\
(n=86) \\
\end{array}$ & \\
\hline a'Median age (years) & 63 & 71 & 61 & 67 & 60 & 71 & 50 & 66 & $\begin{array}{c}<0.001 \text { (controls) } \\
0.002 \text { (cases) }\end{array}$ \\
\hline $\begin{array}{l}{ }^{\mathrm{b}} \text { Median PSA } \\
(\mathrm{ng} / \mathrm{mL})\end{array}$ & 0.8 & 14.3 & 0.9 & 19.3 & 1.4 & 47.8 & 1.2 & 57.5 & $\begin{array}{c}<0.001 \text { (controls) } \\
<0.001 \text { (cases) }\end{array}$ \\
\hline${ }^{\ddagger}$ Gleason $\geq 7$ & & $\begin{array}{c}34 / 78 \\
(43.6 \%)\end{array}$ & & $\begin{array}{c}62 / 130 \\
(47.7 \%)\end{array}$ & & $\begin{array}{c}9 / 12 \\
(75.0 \%)\end{array}$ & & $\begin{array}{l}34 / 76 \\
(40.5)\end{array}$ & 0.146 (cases) \\
\hline${ }^{\ddagger}$ Stage $3 / 4$ & & $\begin{array}{c}35 / 104 \\
(33.7 \%)\end{array}$ & & $\begin{array}{c}85 / 203 \\
(41.9 \%)\end{array}$ & & $\begin{array}{c}14 / 24 \\
(58.3 \%)\end{array}$ & & $\begin{array}{c}35 / 78 \\
(44.9 \%)\end{array}$ & 0.121 (cases) \\
\hline${ }^{\ddagger}$ Metastasis & & $\begin{array}{c}3 / 100 \\
(3.0 \%)\end{array}$ & & $\begin{array}{c}21 / 196 \\
(10.7 \%)\end{array}$ & & $\begin{array}{c}3 / 22 \\
(13.6 \%)\end{array}$ & & $\begin{array}{c}14 / 86 \\
(16.3 \%)\end{array}$ & 0.003 (cases) \\
\hline
\end{tabular}

${ }^{a}$ For each of the respective population groups, $P \leq 0.05$ when comparing the median age between cases versus controls.

${ }^{\mathrm{b}}$ For each of the respective population groups, $P \leq 0.05$ when comparing the median PSA between cases versus controls.

${ }^{\ddagger}$ Gleason score, tumor stage and/or metastases information were missing from the medical records of some of the clinically confirmed prostate cancer cases. Therefore, the numbers and percentages shown are for the available information, and not that of the total number of cases included in the study for each population group.

[19]. The SRD5A2 polymorphisms rs9282858 (A49T) and rs523349 (V89L) for both sets of samples were analyzed using the methods described by Zeigler-Johnson and colleagues [28].

2.4. Statistical Analysis. Analyses were undertaken to compare the association of prostate cancer, advanced tumor stage, and Gleason scores with the presence of androgen metabolism variants. Results were stratified by sample population. Descriptive analyses for discrete traits were carried out using contingency table methods and the Fisher's exact tests (FET) or chi-square statistics. Medians were used to summarize continuously distributed traits. Unconditional logistic regression was used to examine population differences in the odds of having advanced disease at diagnosis. Genotypes for each gene were analyzed in separate models using the homozygous wild type as the comparison group. All analyses were adjusted for age. Statistical heterogeneity among groups was tested using the Mantel-Haenszel test of independence. To minimize the effect of potential false-positive genetic associations due to the small sample sizes of the individual population groups, we combined the genotype data by country (combined South African versus Senegalese) and by non-Black versus Black (Mixed Ancestry/White versus South African Black/Senegalese) (due to the significant ancestral contributions of other populations, we categorized the Mixed Ancestry as non-Black). Previously, we corrected for population stratification in a South African Mixed Ancestry group and in a combined Mixed Ancestry/White group, by applying a genomic control inflation factor value, lambda $(\lambda)[27,29]$. Given that $\lambda$ may increase with sample size, in the present study we applied a more stringent correction for population stratification by using a calculated $\lambda_{1,000}$ [30], an adjusted inflation factor assuming an equivalent study of 1,000 cases and 1,000 controls. Consequently, upon applying this correction for our association analyses, only observed $P$ values of less than and equal to 0.0041 were considered statistically significant for the Mixed Ancestry and the combined Mixed Ancestry/White group; this $P$ value was also applied when the Mixed Ancestry was combined with South African White and Black groups. A two-sided $P$ value of 0.05 or less was considered statistically significant for the South African White, Black, Senegalese, and the combined South African Black/Senegalese group.

\section{Results and Discussion}

The median age at diagnosis of prostate cancer and the median age of the controls was significantly different among the groups (Table 1). Senegalese were the youngest for both controls (median age 50) and cases (median age 66). Median PSA level of Senegalese cases was higher than levels of South African Black, Mixed Ancestry, and White cases $(57.5 \mathrm{ng} / \mathrm{mL}$ versus $47.8 \mathrm{ng} / \mathrm{mL}, 19.3 \mathrm{ng} / \mathrm{mL}$, and $14.3 \mathrm{ng} / \mathrm{mL}$ ) (Table 1). Previous studies also demonstrated that Senegalese men have higher PSA levels than African-American, CaucasianAmerican, and Asian-Indian men [13, 14], although the high PSA in Senegalese men does not appear to correlate with higher levels of aggressive disease. South African Black men showed the highest proportion of advanced disease (high-stage tumors T3/T4) (Table 1). Advanced disease could be linked to seeking potentially curative therapy at a later age when the disease may be at a much more advanced stage. However, Heyns and colleagues [12] and the present study showed the that South African Black men generally present with clinical features at a similar age to men from other groups. Therefore, these data might suggest that South African Black men are predisposed to develop more aggressive disease. Overall, metastasis was observed more often in Senegalese men than in South African men 
TABLE 2: Frequency of genotypes among South African and Senegalese prostate cancer cases and controls.

\begin{tabular}{|c|c|c|c|c|c|c|c|c|c|c|}
\hline \multirow{3}{*}{$\begin{array}{l}\text { Genotypes } \\
\text { Genes }\end{array}$} & \multicolumn{8}{|c|}{ South Africa } & \multirow{2}{*}{\multicolumn{2}{|c|}{$\begin{array}{c}\text { Senegal } \\
\text { Senegalese }\end{array}$}} \\
\hline & \multicolumn{2}{|c|}{ White } & \multicolumn{2}{|c|}{ Mixed } & \multicolumn{2}{|c|}{ Black } & \multicolumn{2}{|c|}{ Combined } & & \\
\hline & $\begin{array}{c}\text { Controls } \\
(n=134)\end{array}$ & $\begin{array}{c}\text { Cases } \\
(n=120)\end{array}$ & $\begin{array}{c}\text { Controls } \\
(n=167)\end{array}$ & $\begin{array}{c}\text { Cases } \\
(n=207)\end{array}$ & $\begin{array}{c}\text { Controls } \\
(n=20)\end{array}$ & $\begin{array}{c}\text { Cases } \\
(n=25)\end{array}$ & $\begin{array}{c}\text { Controls } \\
(n=321)\end{array}$ & $\begin{array}{c}\text { Cases } \\
(n=352)\end{array}$ & $\begin{array}{c}{ }^{\ddagger} \text { Controls } \\
(n=300)\end{array}$ & $\begin{array}{c}{ }^{\ddagger} \text { Cases } \\
(n=86)\end{array}$ \\
\hline \multicolumn{11}{|c|}{ CYP3A4 (rs2740574) } \\
\hline AA & $\begin{array}{c}122 \\
(91.0 \%)\end{array}$ & $\begin{array}{c}84 \\
(70.0 \%)\end{array}$ & $\begin{array}{c}117 \\
(70.1 \%)\end{array}$ & $\begin{array}{c}82 \\
(39.6 \%)\end{array}$ & $\begin{array}{c}2 \\
(10.0 \%)\end{array}$ & $\begin{array}{c}9 \\
(36.0 \%)\end{array}$ & $\begin{array}{c}241 \\
(75.1 \%)\end{array}$ & $\begin{array}{c}175 \\
(49.7 \%)\end{array}$ & $\begin{array}{c}21 \\
(7.5 \%)\end{array}$ & $\begin{array}{c}6 \\
(7.1 \%)\end{array}$ \\
\hline AG & $\begin{array}{c}12 \\
(9.0 \%)\end{array}$ & $\begin{array}{c}34 \\
(28.3 \%)\end{array}$ & $\begin{array}{c}49 \\
(29.3 \%)\end{array}$ & $\begin{array}{c}111 \\
(53.6 \%)\end{array}$ & $\begin{array}{c}15 \\
(75.0 \%)\end{array}$ & $\begin{array}{c}16 \\
(64.0 \%)\end{array}$ & $\begin{array}{c}76 \\
(23.7 \%)\end{array}$ & $\begin{array}{c}161 \\
(45.7 \%)\end{array}$ & $\begin{array}{c}91 \\
(32.3 \%)\end{array}$ & $\begin{array}{c}40 \\
(47.6 \%)\end{array}$ \\
\hline GG & $\begin{array}{c}0 \\
(0 \%) \\
\end{array}$ & $\begin{array}{c}2 \\
(1.7 \%) \\
\end{array}$ & $\begin{array}{c}1 \\
(0.6 \%)\end{array}$ & $\begin{array}{c}14 \\
(6.8 \%) \\
\end{array}$ & $\begin{array}{c}3 \\
(15.0 \%) \\
\end{array}$ & $\begin{array}{c}0 \\
(0 \%) \\
\end{array}$ & $\begin{array}{c}4 \\
(1.2 \%) \\
\end{array}$ & $\begin{array}{c}16 \\
(4.6 \%) \\
\end{array}$ & $\begin{array}{c}170 \\
(60.3 \%) \\
\end{array}$ & $\begin{array}{c}38 \\
(45.2 \%) \\
\end{array}$ \\
\hline \multicolumn{11}{|c|}{ CYP3A5 (rs776746) } \\
\hline GG & $\begin{array}{c}113 \\
(84.3 \%)\end{array}$ & $\begin{array}{c}95 \\
(79.2 \%)\end{array}$ & $\begin{array}{c}58 \\
(34.7 \%)\end{array}$ & $\begin{array}{c}58 \\
(28.0 \%)\end{array}$ & $\begin{array}{c}1 \\
(5.0 \%)\end{array}$ & $\begin{array}{c}1 \\
(4.0 \%)\end{array}$ & $\begin{array}{c}172 \\
(53.6 \%)\end{array}$ & $\begin{array}{c}154 \\
(43.8 \%)\end{array}$ & $\begin{array}{c}14 \\
(5.3 \%)\end{array}$ & $\begin{array}{c}4 \\
(5.1 \%)\end{array}$ \\
\hline$A G$ & $\begin{array}{c}18 \\
(13.4 \%)\end{array}$ & $\begin{array}{c}22 \\
(18.3 \%)\end{array}$ & $\begin{array}{c}72 \\
(43.1 \%)\end{array}$ & $\begin{array}{c}106 \\
(51.2 \%)\end{array}$ & $\begin{array}{c}5 \\
(25.0 \%)\end{array}$ & $\begin{array}{c}5 \\
(20.0 \%)\end{array}$ & $\begin{array}{c}95 \\
(29.6 \%)\end{array}$ & $\begin{array}{c}133 \\
(37.8 \%)\end{array}$ & $\begin{array}{c}66 \\
(25.1 \%)\end{array}$ & $\begin{array}{c}20 \\
(25.3 \%)\end{array}$ \\
\hline AA & $\begin{array}{c}3 \\
(2.3 \%) \\
\end{array}$ & $\begin{array}{c}3 \\
(2.5 \%) \\
\end{array}$ & $\begin{array}{c}37 \\
(22.2 \%) \\
\end{array}$ & $\begin{array}{c}43 \\
(20.8 \%)\end{array}$ & $\begin{array}{c}14 \\
(70.0 \%)\end{array}$ & $\begin{array}{c}19 \\
(76.0 \%)\end{array}$ & $\begin{array}{c}54 \\
(16.8 \%)\end{array}$ & $\begin{array}{c}65 \\
(18.4 \%) \\
\end{array}$ & $\begin{array}{c}183 \\
(69.6 \%) \\
\end{array}$ & $\begin{array}{c}55 \\
(69.6 \%) \\
\end{array}$ \\
\hline \multicolumn{11}{|c|}{ SRD5A2 V89L (rs523349) } \\
\hline GG & $\begin{array}{c}56 \\
(41.8 \%)\end{array}$ & $\begin{array}{c}61 \\
(50.8 \%)\end{array}$ & $\begin{array}{c}96 \\
(57.5 \%)\end{array}$ & $\begin{array}{c}131 \\
(63.3 \%)\end{array}$ & $\begin{array}{c}5 \\
(25.0 \%)\end{array}$ & $\begin{array}{c}16 \\
(64.0 \%)\end{array}$ & $\begin{array}{c}157 \\
(48.9 \%)\end{array}$ & $\begin{array}{c}208 \\
(59.1 \%)\end{array}$ & $\begin{array}{c}26 \\
(12.2 \%)\end{array}$ & $\begin{array}{c}10 \\
(14.1 \%)\end{array}$ \\
\hline CG & $\begin{array}{c}70 \\
(52.2 \%)\end{array}$ & $\begin{array}{c}51 \\
(42.5 \%)\end{array}$ & $\begin{array}{c}65 \\
(38.9 \%)\end{array}$ & $\begin{array}{c}71 \\
(34.3 \%)\end{array}$ & $\begin{array}{c}7 \\
(35.0 \%)\end{array}$ & $\begin{array}{c}7 \\
(28.0 \%)\end{array}$ & $\begin{array}{c}142 \\
(44.2 \%)\end{array}$ & $\begin{array}{c}129 \\
(36.6 \%)\end{array}$ & $\begin{array}{c}61 \\
(28.5 \%)\end{array}$ & $\begin{array}{c}10 \\
(14.1 \%)\end{array}$ \\
\hline $\mathrm{CC}$ & $\begin{array}{c}8 \\
(6.0 \%) \\
\end{array}$ & $\begin{array}{c}8 \\
(6.7 \%)\end{array}$ & $\begin{array}{c}6 \\
(3.6 \%)\end{array}$ & $\begin{array}{c}5 \\
(2.4 \%) \\
\end{array}$ & $\begin{array}{c}8 \\
(40.0 \%)\end{array}$ & $\begin{array}{c}2 \\
(8.0 \%)\end{array}$ & $\begin{array}{c}22 \\
(6.9 \%)\end{array}$ & $\begin{array}{c}15 \\
(4.3 \%)\end{array}$ & $\begin{array}{c}127 \\
(59.4 \%)\end{array}$ & $\begin{array}{c}51 \\
(71.8 \%)\end{array}$ \\
\hline \multicolumn{11}{|c|}{ SRD5A2 A49T (rs9282858) } \\
\hline GG & $\begin{array}{c}107 \\
(79.8 \%)\end{array}$ & $\begin{array}{c}90 \\
(75.0 \%)\end{array}$ & $\begin{array}{c}127 \\
(76.0 \%)\end{array}$ & $\begin{array}{c}120 \\
(58.0 \%)\end{array}$ & $\begin{array}{c}10 \\
(50.0 \%)\end{array}$ & $\begin{array}{c}17 \\
(68.0 \%)\end{array}$ & $\begin{array}{c}244 \\
(76.0 \%)\end{array}$ & $\begin{array}{c}227 \\
(64.5 \%)\end{array}$ & $\begin{array}{c}278 \\
(100.0 \%)\end{array}$ & $\begin{array}{c}75 \\
(100.0 \%)\end{array}$ \\
\hline GA & $\begin{array}{c}27 \\
(20.2 \%)\end{array}$ & $\begin{array}{c}30 \\
(25.0 \%)\end{array}$ & $\begin{array}{c}40 \\
(24.0 \%)\end{array}$ & $\begin{array}{c}87 \\
(42.0 \%)\end{array}$ & $\begin{array}{c}10 \\
(50.0 \%)\end{array}$ & $\begin{array}{c}8 \\
(32.0 \%)\end{array}$ & $\begin{array}{c}77 \\
(24.0 \%)\end{array}$ & $\begin{array}{c}125 \\
(35.5 \%)\end{array}$ & $\begin{array}{c}0 \\
(0 \%)\end{array}$ & $\begin{array}{c}0 \\
(0.0 \%)\end{array}$ \\
\hline
\end{tabular}

$P<0.001$, for each polymorphism when comparing across each of the respective population groups for cases or for controls.

‡ Some participants had missing genotype data. The numbers and percentages shown are for the available information.

(16.3\% versus $13.6 \%$ among Black South African, $10.7 \%$ Mixed Ancestry, and 3.0\% White South African) (Table 1). A possible reason for this may be that the Senegalese men have a better follow-up schedule [13], whereas many South African men were lost to follow-up or the mean duration of follow-up was short, particularly for men with higher-stage and grade disease [12].

We noted significant genotype frequency differences between the South African ethnic groups, as well as between the South African and Senegalese populations (Table 2). There were significant differences in allele frequencies between the South African and Senegalese groups for CYP3A4 and SRD5A2 (Figure 1). Conversely, the frequencies for the CYP3A5 rs776746 A-allele were not significantly different in South African Black and Senegalese men (Figure 1). These data might suggest that the diverse populations with African ancestry might share some common prostate cancer susceptibility alleles that may be different than the nonAfrican populations.

A positive association was observed between the CYP3A4 rs2740574 AG and AG/GG genotypes and prostate cancer in South African White and Mixed Ancestry men and the

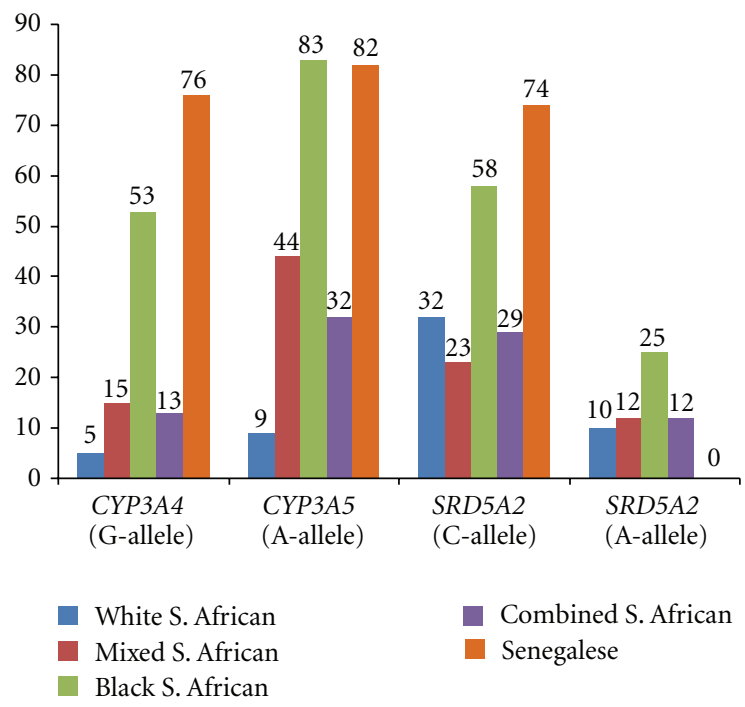

FIGURE 1: Minor allele frequencies among South African and Senegalese controls. 
TABLE 3: South African and Senegalese case-control genotype associations with prostate cancer (adjusted for age).

\begin{tabular}{|c|c|c|c|c|}
\hline \multirow{2}{*}{ Variables of interest } & \multicolumn{3}{|c|}{ South Africa } & \multirow{2}{*}{$\begin{array}{c}\text { Senegal } \\
\text { Senegalese }\end{array}$} \\
\hline & White & Mixed & Black & \\
\hline Genotypes & OR $(95 \% \mathrm{CI})$ & OR (95\% CI) & OR $(95 \% \mathrm{CI})$ & OR (95\% CI) \\
\hline \multicolumn{5}{|l|}{ CYP3A4 (rs2740574) } \\
\hline AA & 1.00 (ref) & 1.00 (ref) & 1.00 (ref) & 1.00 (ref) \\
\hline AG & $3.32(1.52-7.24)^{*}$ & $3.38(2.13-5.35)^{* *}$ & $0.21(0.03-1.32)$ & $1.51(0.52-4.38)$ \\
\hline GG & - & $4.57(1.63-12.85)$ & - & $0.94(0.54-1.65)$ \\
\hline AG/GG & $3.63(1.68-7.84)^{*}$ & $3.74(2.37-5.89)^{* *}$ & $0.18(0.03-1.16)$ & $1.13(0.40-3.22)$ \\
\hline \multicolumn{5}{|l|}{ CYP3A5 (rs776746) } \\
\hline GG & 1.00 (ref) & 1.00 (ref) & 1.00 (ref) & 1.00 (ref) \\
\hline AG & $1.14(0.55-2.37)$ & $1.68(1.02-2.76)$ & $1.31(0.36-29.51)$ & $0.98(0.18-5.39)$ \\
\hline $\mathrm{AA}$ & $1.14(0.46-2.79)$ & $1.21(0.89-1.64)$ & $1.65(0.38-7.15)$ & $0.99(0.50-1.99)$ \\
\hline AG/AA & $1.17(0.59-2.32)$ & $1.61(1.01-2.57)$ & $2.21(0.12-39.39)$ & $0.98(0.24-3.97)$ \\
\hline \multicolumn{5}{|c|}{ SRD5A2 V89L (rs523349) } \\
\hline GG & 1.00 (ref) & 1.00 (ref) & 1.00 (ref) & 1.00 (ref) \\
\hline CG & $0.71(0.41-1.24)$ & $0.74(0.48-1.16)$ & $0.26(0.04-1.54)$ & $0.36(0.12-1.07)$ \\
\hline $\mathrm{CC}$ & $0.86(0.49-1.50)$ & $0.78(0.41-1.48)$ & $0.17(0.04-0.66)^{*}$ & $0.98(0.60-1.59)$ \\
\hline CG/CC & $0.71(0.41-1.22)$ & $0.73(0.47-1.13)$ & $0.14(0.03-0.66)^{*}$ & $0.74(0.30-1.86)$ \\
\hline \multicolumn{5}{|c|}{ SRD5A2 A49T (rs9282858) } \\
\hline GG & 1.00 (ref) & 1.00 (ref) & 1.00 (ref) & 1.00 (ref) \\
\hline AG & $1.02(0.54-1.95)$ & $2.31(1.45-3.68)^{* *}$ & $0.43(0.11-1.69)$ & - \\
\hline $\mathrm{AA}$ & - & - & - & - \\
\hline AG/AA & $1.02(0.54-1.95)$ & $2.31(1.45-3.68)^{* *}$ & $0.43(0.11-1.69)$ & - \\
\hline
\end{tabular}

-: too few/no genotypes to estimate ORs.

$* P<0.05$.

** $P<0.0041$.

SRD5A2 rs9282858 AG and AG/AA genotypes in Mixed Ancestry men, whereas the SRD5A2 rs523349 CC and CG/CC genotypes demonstrated an inverse association with the disease in Black South Africans (Table 3). When we combined the groups by country, only the CYP3A4 rs2740574 association remained significant (Table 4). Combining the groups by non-Black versus Black, the association with the CYP3A4 rs2740574 AG and AG/GG genotype was significant in the combined South African Mixed Ancestry/White group, and an inverse association was observed for the SRD5A2 523349 CG, CC and CG/CC genotypes in the combined South African Black/Senegalese group (Table 5). We consistently observed the associations with CYP3A4 rs2740574 polymorphism, of which the variant G-allele has been shown to have no functional consequence [31]. Our data support numerous associations reported in other populations [17-19]. However, given that the polymorphism has no functional consequence, the CYP3A4 rs2740574 associations reported in various populations are unlikely to be causal and might in fact reflect the influence of a nearby variant in linkage disequilibrium (LD). For SRD5A2, the variant A-allele of the rs9282858 polymorphism has been shown to cause the steroid 5-alpha reductase enzyme to have a higher $V \max$ compared to the wild-type enzyme [32]. Given that the SDR5A2 rs9282858 association that we observed in Mixed Ancestry men did not remain significant when we combined different groups, we cannot exclude that this association could be spurious due to the small sample size of the individual groups or population stratification. Physiologically, the protective effects we observed for SRD5A2 rs523349 in South African Black and the combined Black/Senegalese group are plausible because the variant Callele, which causes a Valine to Leucine (V89L) amino acid substitution at codon 89 , results in a reduced steroid 5-alpha reductase enzyme activity [33]. Given that the conversion of testosterone to highly active DHT may play an import role in prostate cancer development [34], it stands to reason that a significant reduction in steroid 5-alpha reductase activity may reduce the likelihood of developing prostate cancer.

Stratifying the genotype data according to pathological characteristics, an association was observed with the CYP3A4 rs2740574 AG and AG/GG genotypes and an increased likelihood of developing high-stage and high-grade prostate cancer in Mixed Ancestry, the combined South African and the non-Black (Mixed Ancestry/White) group (data no shown). However, it remains unclear how a "nonfunctional" variant may alter tumor pathology. Additionally, Senegalese men were more than 0.16 -fold ( $84 \%$ ) less likely to develop high-stage prostate cancer if they had the SRD5A2 rs523349 CG genotype (data not shown). These data might lend support for the use of steroid 5-alpha reductase inhibitors to limit progression to advanced disease.

We observed a few possible limitations in our study. Our sample sizes for the individual groups were small (particularly in the Black South African group) and may thus have been underpowered to detect discrete genetic associations. 
TABLE 4: Combined South African and Senegalese case-control genotype associations with prostate cancer (adjusted for age).

\begin{tabular}{|c|c|c|}
\hline Variables of interest & South Africa (Mixed, White and Black) & Senegal \\
\hline Genotypes & OR $(95 \% \mathrm{CI})$ & OR $(95 \% \mathrm{CI})$ \\
\hline \multicolumn{3}{|l|}{ CYP3A4 (rs2740574) } \\
\hline AA & $1.00(\mathrm{ref})$ & $1.00(\mathrm{ref})$ \\
\hline $\mathrm{AG}$ & $3.04(2.13-4.35)^{* *}$ & $1.51(0.52-4.38)$ \\
\hline GG & $3.11(1.63-5.93)$ & $0.94(0.54-1.65)$ \\
\hline AG/GG & $3.27(2.30-4.65)^{* *}$ & $1.13(0.40-3.22)$ \\
\hline \multicolumn{3}{|l|}{ CYP3A5 (rs776746) } \\
\hline GG & 1.00 (ref) & 1.00 (ref) \\
\hline AG & $1.74(1.21-2.51)$ & $0.97(0.18-5.39)$ \\
\hline AA & $1.33(1.05-1.67)$ & $0.99(0.50-1.99)$ \\
\hline AG/AA & $1.74(1.25-2.41)$ & $0.98(0.24-3.97)$ \\
\hline \multicolumn{3}{|c|}{ SRD5A2 V89L (rs523349) } \\
\hline GG & $1.00(\mathrm{ref})$ & 1.00 (ref) \\
\hline CG & $0.66(0.47-0.92)$ & $0.36(0.12-1.07)$ \\
\hline $\mathrm{CC}$ & $0.66(0.45-0.95)$ & $0.98(0.60-1.59)$ \\
\hline CG/CC & $0.62(0.45-0.86)$ & $0.74(0.30-1.86)$ \\
\hline \multicolumn{3}{|c|}{ SRD5A2 A49T (rs9282858) } \\
\hline GG & 1.00 (ref) & $1.00($ ref $)$ \\
\hline AG & $1.70(1.19-2.43)$ & - \\
\hline $\mathrm{AA}$ & - & - \\
\hline AG/AA & $1.70(1.19-2.43)$ & - \\
\hline
\end{tabular}

—: too few/no genotypes to estimate ORs.

${ }^{* *} P<0.0041$.

However, we were sufficiently powered to observe statistical differences in the other groups, especially the mixed South African sample. We computed tests of heterogeneity to determine that there are indeed significant differences in the estimates that were obtained for the primary associations of interest. Specifically, there was significant heterogeneity among the estimates for CYP3A4 rs2740574 $(P<0.001)$ and SRD5A2 rs9282858 $(P=0.021)$. Therefore, in those situations where we are unable to detect a significant association, we may still observe that populations differ from one another in how these genotypes are related to prostate cancer. There are other issues besides small sample size that may contribute to the heterogeneity in associations. Environmental/lifestyle differences among these populations may contribute to gene-environment effects causing differences in association. Linkage disequilibrium with other putative genes such as CYP3A43 (not measured here, but on the same locus as CYP3A4 and CYP3A5) may exist in some populations and not others [19]. In case-control association studies, unobserved population stratification also may act as a confounder, leading to an increased number of false-positive results. The South African Mixed Ancestry population exhibits significant population stratification [9]. We subjected our South African Mixed Ancestry group and the combined South African groups to stringent genomic control correction. This approach may have limitations and ideally, we should use ancestry informative markers (AIMs) to determine the level of substructure in the Mixed Ancestry group, then extrapolate these data to the combined groups. However, there are currently no available AIMs specific for the Mixed Ancestry population that we could use to directly measure the effect of substructure. For the other groups included in the study, we considered the admixture in the Senegalese population to be low [35], that, due to historical separation between South African Black and White population, admixture is also low, or at best, not to the extent seen in the Mixed Ancestry population.

\section{Conclusions}

We investigated the role of androgen metabolism gene polymorphisms in prostate cancer risk and tumor pathology in African men with diverse ancestries. We observed significant differences in allele frequencies between South African and Senegalese individuals. We also established that the allele frequencies were more similar between Senegalese and Black South African men. The magnitude and direction of the effects we observed for CYP3A4 rs274057 were comparable to other studies. For SRD5A2 rs523349, protective effects associated with tumor pathology were seen in Senegalese men, but not in South African men. Our results suggest that, variants previously associated with prostate cancer in other populations may also affect prostate cancer risk and 
TABLE 5: Case-control genotype associations with prostate cancer by non-Black and Black men (adjusted for age).

\begin{tabular}{|c|c|c|}
\hline Variables of interest & Non-Black (South African Mixed and White) & Black (South African Black and Senegalese) \\
\hline Genotypes & OR $(95 \% \mathrm{CI})$ & OR $(95 \% \mathrm{CI})$ \\
\hline \multicolumn{3}{|l|}{ CYP3A4 (rs2740574) } \\
\hline AA & 1.00 (ref) & 1.00 (ref) \\
\hline AG & $3.58(2.44-5.24)^{* *}$ & $0.80(0.35-1.82)$ \\
\hline GG & $5.16(1.85-14.39)$ & $0.65(0.41-1.02)$ \\
\hline AG/GG & $3.95(2.72-5.75)^{* *}$ & $0.59(0.26-1.31)$ \\
\hline \multicolumn{3}{|l|}{ CYP3A5 (rs776746) } \\
\hline GG & 1.00 (ref) & 1.00 (ref) \\
\hline AG & $1.78(1.23-2.58)$ & $1.06(0.24-4.63)$ \\
\hline AA & $1.30(1.00-1.69)$ & $1.08(0.57-2.02)$ \\
\hline AG/AA & $1.75(1.25-2.45)$ & $1.13(0.32-3.98)$ \\
\hline \multicolumn{3}{|c|}{ SRD5A2 V89L (rs523349) } \\
\hline GG & 1.00 (ref) & 1.00 (ref) \\
\hline CG & $0.68(0.48-0.96)$ & $0.26(0.11-0.61)^{*}$ \\
\hline $\mathrm{CC}$ & $0.79(0.52-1.20)$ & $0.67(0.46-0.97)^{*}$ \\
\hline CG/CC & $0.67(0.48-0.94)$ & $0.38(0.19-0.77)^{*}$ \\
\hline \multicolumn{3}{|c|}{ SRD5A2 A49T (rs9282858) } \\
\hline GG & 1.00 (ref) & 1.00 (ref) \\
\hline AG & $1.88(1.30-2.73)$ & $1.40(0.48-4.12)$ \\
\hline AA & - & - \\
\hline AG/AA & $1.88(1.30-2.73)$ & $1.40(0.48-4.12)$ \\
\hline
\end{tabular}

—: too few/no genotypes to estimate ORs.

$* P<0.05$.

** $P<0.0041$.

tumor aggressiveness in African men. Given that ethnicity is considered a significant risk factor for prostate cancer, the comparative analyses in diverse African populations may help to elucidate the underlying genetic etiolgies of the disease.

\section{Authors' Contribution}

P. Fernandez and C. M. Zeigler-Johnson contributed equally to this paper.

\section{Conflict of Interests}

The authors declare that they have no conflict of interests.

\section{Acknowledgments}

The authors would like to thank all the participants of the study, and the urologists who facilitated the collection of samples. The study on South African men was supported by the Medical Research Council (MRC) of South Africa and the Hayes Fund of Stellenbosch University (P. Fernandez). Even though the work is supported by the MRC, the views and opinions expressed are not those of the MRC but of the authors of the material produced or publicised. The PROGRES (Prostate-Genetique-Recherche-Senegal) Study in Senegal was supported by R03-CA103359 (to S. M. Gueye) and the R01-CA085074 (to T. R. Rebbeck).

\section{References}

[1] J. Ferlay, H. R. Shin, F. Bray, D. Forman, C. Mathers, and D. M. Parkin, "Estimates of worldwide burden of cancer in 2008: GLOBOCAN 2008," International Journal of Cancer, vol. 127, no. 12, pp. 2893-2917, 2010.

[2] A. Jemal, F. Bray, M. M. Center, J. Ferlay, E. Ward, and D. Forman, "Global cancer statistics," CA: A Cancer Journal for Clinicians, vol. 61, no. 2, pp. 69-90, 2011.

[3] M. M. Center, A. Jemal, J. Lortet-Tieulent et al., "International variation in prostate cancer incidence and mortality rates," European Urology, vol. 61, no. 6, pp. 1079-1092, 2012.

[4] N. B. Delongchamps, A. Singh, and G. P. Haas, "Epidemiology of prostate cancer in Africa: another step in the understanding of the disease?" Current Problems in Cancer, vol. 31, no. 3, pp. 226-236, 2007.

[5] E. A. Platz and E. Giovannucci, "Prostate cancer," in Cancer Epidemiology and Prevention, D. Schottenfeld and J. F. Fraumeni, Eds., pp. 1128-1150, Oxford University Press, New York, NY, USA, 2006.

[6] F. T. Odedina, T. O. Akinremi, F. Chinegwundoh et al., "Prostate cancer disparities in Black men of African descent: a comparative literature review of prostate cancer burden among Black men in the United States, Caribbean, United Kingdom, and West Africa," Infectious Agents and Cancer, vol. 4, supplement 1, article S2, 2009. 
[7] D. M. Parkin, F. Sitas, M. Chirenje, L. Stein, R. Abratt, and H. Wabinga, "Part I: cancer in indigenous Africans-burden, distribution, and trends," The Lancet Oncology, vol. 9, no. 7, pp. 683-692, 2008.

[8] A. Jemal, F. Bray, D. Forman et al., "Cancer burden in Africa and opportunities for prevention," Cancer, vol. 118, no. 18, pp. 4372-4384, 2012.

[9] E. de Wit, W. Delport, C. E. Rugamika et al., "Genomewide analysis of the structure of the South African Coloured Population in the Western Cape," Human Genetics, vol. 128, no. 2, pp. 145-153, 2010.

[10] N. Mqoqi, P. Kellett, F. Sitas, and M. Jula, "Incidence of histologically diagnosed cancer in South Africa, 1998-1999," in National Cancer Registry Johannesburg, National Cancer Registry of South Africa, 2004.

[11] C. F. Heyns, S. Mathee, A. Isaacs, A. Kharwa, P. M. de Beer, and M. A. Pretorius, "Problems with prostate specific antigen screening for prostate cancer in the primary healthcare setting in South Africa," BJU International, vol. 91, no. 9, pp. 785-788, 2003.

[12] C. F. Heyns, M. Fisher, A. Lecuona, and A. van der Merwe, "Prostate cancer among different racial groups in the western cape: presenting features and management," South African Medical Journal, vol. 101, no. 4, pp. 267-270, 2011.

[13] S. M. Gueye, C. M. Zeigler-Johnson, T. Friebel et al., "Clinical characteristics of prostate cancer in African Americans, American whites, and Senegalese men," Urology, vol. 61, no. 5, pp. 987-992, 2003.

[14] C. M. Zeigler-Johnson, H. Rennert, R. D. Mittal et al., "Evaluation of prostate cancer characteristics in four populations worldwide," The Canadian Journal of Urology, vol. 15, no. 3, pp. 4056-4064, 2008.

[15] L. Niang, C. N. Kouka, M. Jalloh, and S. M. Gueye, "Screening for prostate cancer by digital rectal examination and PSA determination in Senegal," ISRN Oncology, vol. 2011, Article ID 943704, 4 pages, 2011.

[16] M. C. Parkinson, "Pre-neoplastic lesions of the prostate," Histopathology, vol. 27, no. 4, pp. 301-311, 1995.

[17] R. A. Kittles, W. Chen, R. K. Panguluri et al., "CYP3A4-V and prostate cancer in African Americans: causal or confounding association because of population stratification?" Human Genetics, vol. 110, no. 6, pp. 553-560, 2002.

[18] S. J. Plummer, D. V. Conti, P. L. Paris, A. P. Curran, G. Casey, and J. S. Witte, "CYP3A4 and CYP3A5 genotypes, haplotypes, and risk of prostate cancer," Cancer Epidemiology Biomarkers and Prevention, vol. 12, no. 9, pp. 928-932, 2003.

[19] C. Zeigler-Johnson, T. Friebel, A. H. Walker et al., "CYP3A4, CYP3A5, and CYP3A43 genotypes and haplotypes in the etiology and severity of prostate cancer," Cancer Research, vol. 64, no. 22, pp. 8461-8467, 2004.

[20] A. Stone, L. D. Ratnasinghe, G. L. Emerson et al., "CYP3A43 Pro340 Ala polymorphism and prostate cancer risk in African Americans and Caucasians," Cancer Epidemiology Biomarkers and Prevention, vol. 14, no. 5, pp. 1257-1261, 2005.

[21] T. R. Rebbeck, H. Rennert, A. H. Walker et al., "Joint effects of inflammation and androgen metabolism on prostate cancer severity," International Journal of Cancer, vol. 123, no. 6, pp. 1385-1389, 2008.

[22] J. M. Jaffe, S. B. Malkowicz, A. H. Walker et al., "Association of SRD5A2 genotype and pathological characteristics of prostate tumors," Cancer Research, vol. 60, no. 6, pp. 1626-1630, 2000.

[23] M. S. Cicek, D. V. Conti, A. Curran et al., "Association of prostate cancer risk and aggressiveness to androgen pathway genes: SRD5A2, CYP17, and the AR," Prostate, vol. 59, no. 1, pp. 69-76, 2004.

[24] V. M. Hayes, G. Severi, E. J. D. Padilla et al., " $5 \alpha$-reductase type 2 gene variant associations with prostate cancer risk, circulating hormone levels and androgenetic alopecia," International Journal of Cancer, vol. 120, no. 4, pp. 776-780, 2007.

[25] C. Neslund-Dudas, C. H. Bock, K. Monaghan et al., "SRD5A2 and HSD3B2 polymorphisms are associated with prostate cancer risk and aggressiveness," Prostate, vol. 67, no. 15, pp. 1654-1663, 2007.

[26] C. Paz-y-Miño, T. Witte, P. Robles, W. Llumipanta, M. Díaz, and M. Arévalo, "Association among polymorphisms in the steroid $5 \alpha$-reductase type II (SRD5A2) gene, prostate cancer risk, and pathologic characteristics of prostate tumors in an Ecuadorian population," Cancer Genetics and Cytogenetics, vol. 189, no. 2, pp. 71-76, 2009.

[27] P. Fernandez, P. D. de Beer, L. D. van der Merwe, and C. F. Heyns, "Genetic variations in androgen metabolism genes and associations with prostate cancer in South African men," South African Medical Journal, vol. 100, no. 11, pp. 741-745, 2010.

[28] C. M. Zeigler-Johnson, A. H. Walker, B. Mancke et al., "Ethnic differences in the frequency of prostate cancer susceptibility alleles at SRD5A2 and CYP3A4," Human Heredity, vol. 54, no. 1, pp. 13-21, 2002.

[29] P. Fernandez, P. M. de Beer, L. van der Merwe, and C. F. Heyns, "COX-2 promoter polymorphisms and the association with prostate cancer risk in South African men," Carcinogenesis, vol. 29, no. 12, pp. 2347-2350, 2008.

[30] M. L. Freedman, D. Reich, K. L. Penney et al., "Assessing the impact of population stratification on genetic association studies," Nature Genetics, vol. 36, no. 4, pp. 388-393, 2004.

[31] A. B. Spurdle, B. Goodwin, E. Hodgson et al., "The CYP3A4* $1 \mathrm{~B}$ polymorphism has no functional significance and is not associated with risk of breast or ovarian cancer," Pharmacogenetics, vol. 12, no. 5, pp. 355-366, 2002.

[32] N. M. Makridakis, R. K. Ross, M. C. Pike et al., "Association of mis-sense substitution in SRD5A2 gene with prostate cancer in African-American and Hispanic men in Los Angeles, USA," The Lancet, vol. 354, no. 9183, pp. 975-978, 1999.

[33] N. Makridakis, R. K. Ross, M. C. Pike et al., "A prevalent missense substitution that modulates activity of prostatic steroid $5 \alpha$-reductase," Cancer Research, vol. 57, no. 6, pp. 1020-1022, 1997.

[34] V. Petrow, "The dihydrotestosterone (DHT) hypothesis of prostate cancer and its therapeutic implications," Prostate, vol. 9, no. 4, pp. 343-361, 1986.

[35] K. Stefflova, M. C. Dulik, A. A. Pai et al., "Evaluation of group genetic ancestry of populations from Philadelphia and Dakar in the context of sex-biased admixture in the Americas," PLoS ONE, vol. 4, no. 11, Article ID e7842, 2009. 


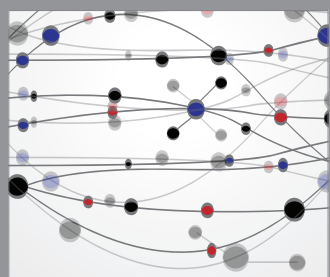

The Scientific World Journal
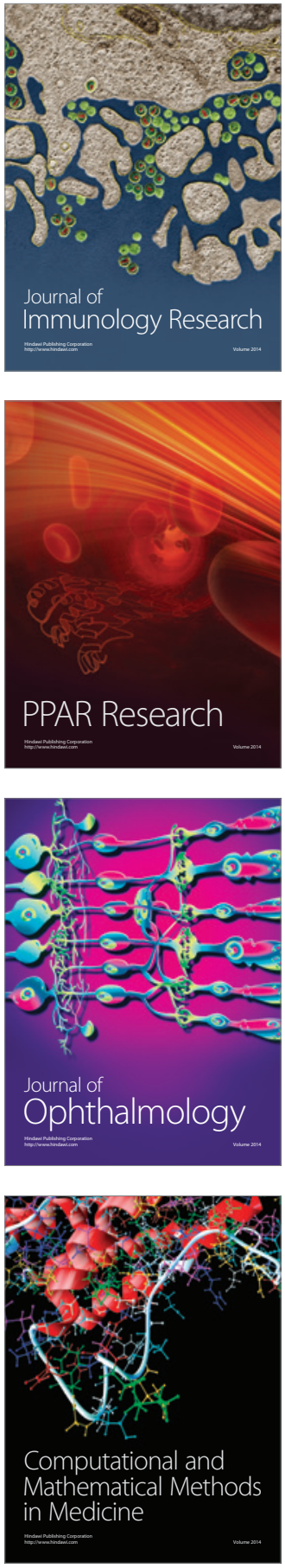

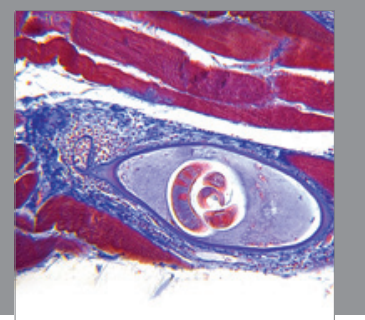

Gastroenterology

Research and Practice
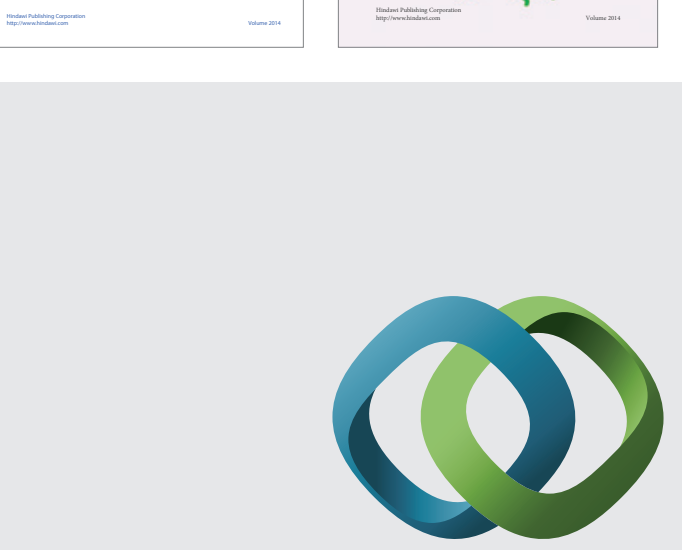

\section{Hindawi}

Submit your manuscripts at

http://www.hindawi.com
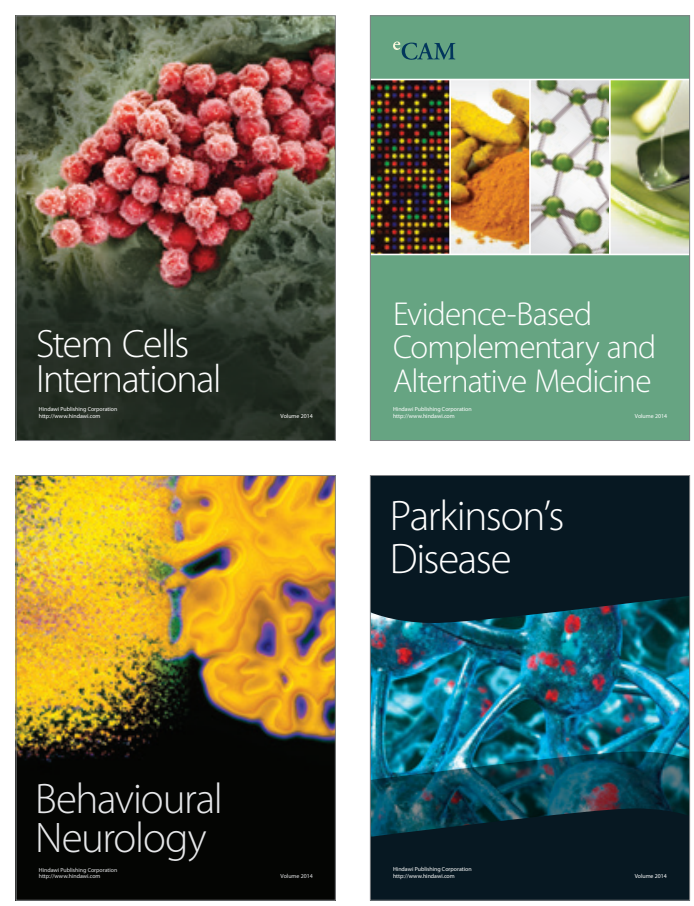

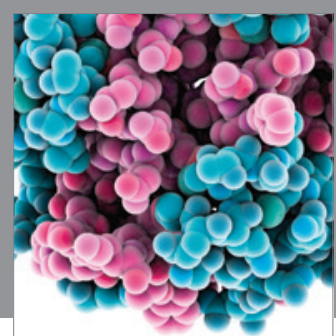

Journal of
Diabetes Research

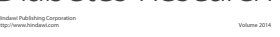

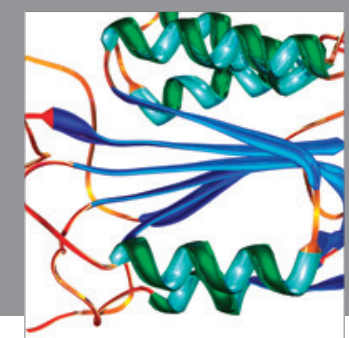

Disease Markers
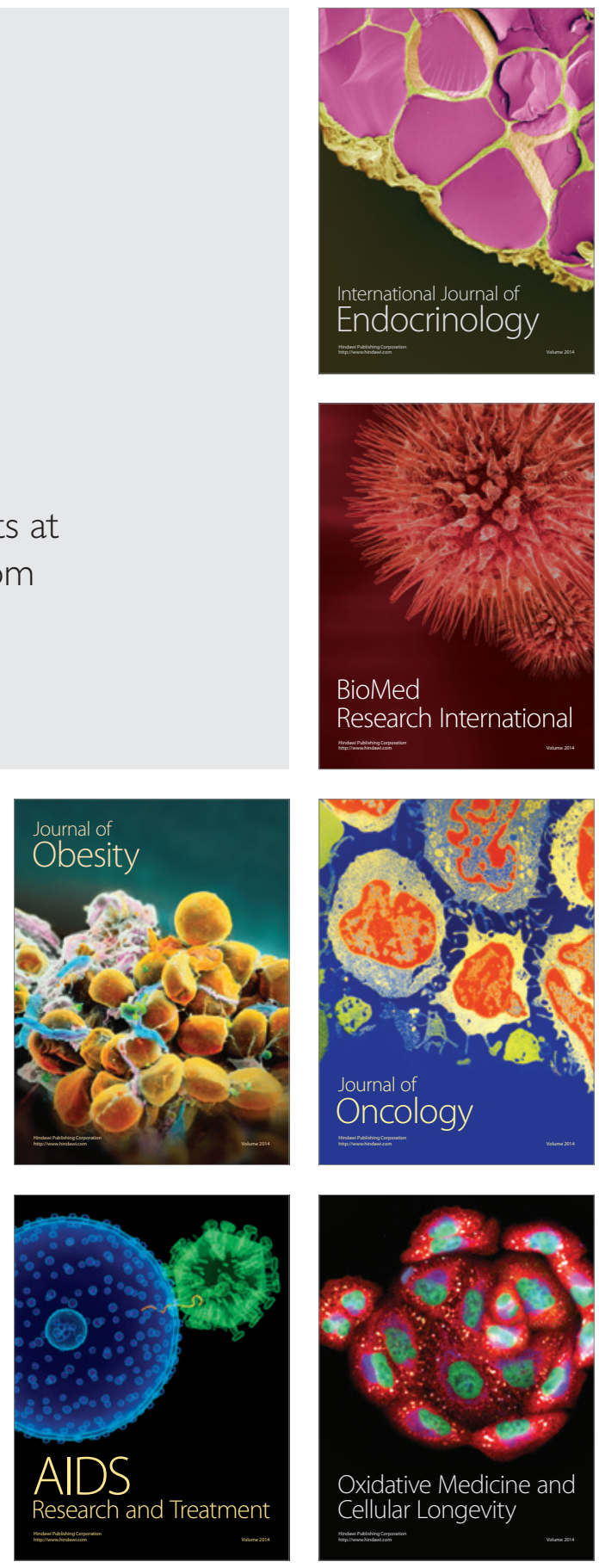